7. of Modern African Studies, 40, 3 (2002), pp. 369-393. (C) 2002 Cambridge University Press DOI: I0.IoI7/Soo22278X02003968 Printed in the United Kingdom

\title{
The management of border disputes in African regional sub- systems: comparing West Africa and the Horn of Africa
}

\author{
Markus Kornprobst*
}

A BSTRACT

In Africa, the management of border disputes varies from sub-region to subregion. Most puzzling is the difference between West Africa and the Horn of Africa. In the latter, border disputes are much more likely to escalate into war than in the former. Seeking to solve this puzzle, this study focuses on the territorial integrity norm. It departs from existing accounts of this norm in two ways: first, it does not choose the region but the sub-region as the level of analysis. Second, it does not isolate the territorial integrity norm from its social context but analyses the interplay of the norm with the social structure in which it is embedded. It concludes that the territorial integrity norm in West Africa is part of a social structure different from that in the Horn of Africa. It is this difference that explains the different patterns of conflict management in the two sub-regions.

\section{INTRODUGTION}

Border disputes are a common feature of African politics. Yet different sub-regions have managed these disputes very differently. This difference is most pronounced between West Africa and the Horn of Africa. West Africa has experienced ten border disputes, none of which erupted into war. In the Horn of Africa, by contrast, only four border disputes occurred, yet two of them resulted in war.

The literature on Africa's territorial order does not account for this variance of conflict management across sub-regions. It holds that there is a region-wide agreement in Africa on the territorial integrity norm (Foltz I 973, I99 I ; Herbst I989; Jackson \& Rosberg I982, г 986, I987). From this argument would follow that, due to a region-wide normative

\footnotetext{
* Doctoral candidate, Department of Political Science, University of Toronto, Toronto, Ontario. I am grateful to Steven Bernstein, Sarah Hipworth, T. V. Paul, Sheila Rusike, and three anonymous referees for helpful comments on earlier drafts. I also wish to thank Emanuel Adler for drawing my attention to the role of colonial experiences in identity discourses.
} 
consensus on territorial integrity, Africa's border disputes do not escalate into war, or at least that they are unlikely to do so across Africa's sub-regions.

This study attempts to explain the difference between the management of border disputes in West Africa and the Horn of Africa. I argue that a different configuration of norms and identity, i.e. different social structures in which the territorial integrity norm is embedded, explains why border disputes are more likely to escalate into war in the Horn of Africa than in West Africa.

This contention is developed in five steps. First, I outline a theoretical framework. Second, I describe the research design of this study. Third, I compare the configuration of norms and identity in West Africa and the Horn. Fourth, I examine the impact of these different configurations on patterns of management of border disputes in West Africa and the Horn of Africa. Fifth, I enquire into the plausibility of alternative explanations. The conclusion summarises my argument and outlines the implications of the results of this study for future research.

THEORETICAL FRAMEWORK

This section criticises the existing literature on the selection of the territorial integrity norm by African states. Based on these criticisms, it chooses the sub-region as a level of analysis, and outlines a sociological - as opposed to a rationalist - framework for the selection of norms.

Several authors contend that there is a global consensus on the territorial integrity norm. Jackson and Rosberg (I987: 519) favour a sociological explanation for this consensus. It is 'an expression of a twentieth-century anticolonial ideology of self-determination'. Zacher (200 I) emphasises the rationalist over the sociological origins of the consensus. It is primarily the fear of the costs of territorial revisionism that makes states select the territorial integrity norm.

The norm of territorial integrity features prominently in the literature on Africa's regional system. There is an agreement in the literature that a region-wide consensus on the territorial integrity norm exists, and that the consensus is due to rationally calculating élites. Foltz (I973, I99 I) maintains that this consensus is a function of weak élites who attempt to minimise external threats to their rule. Herbst (I989) contends that the consensus is the rational answer to the demographic and ethnographic structure of the continent.

There are two problems with these arguments. First, their 
explanatory power is limited because of the level of analysis their authors choose. In Africa, the extent of challenges to territorial integrity varies significantly across sub-regions. The management patterns of border disputes in West Africa and the Horn of Africa are almost diametrically opposed. Arguments that assume a constant, region-wide or even a global consensus on the territorial integrity norm cannot account for this variance. The appropriate level of analysis for this study is therefore the sub-regional level.

Second, it is problematic to analyse the selection and the impact of the territorial integrity norm in isolation from the social structure in which the norm is embedded. Whether ideas are selected as norms or not depends to a considerable extent on their compatibility with the existing social structure. This structure is made up of norms and identity (Bernstein 2002; Finnemore \& Sikkink ı999; Florini ı 996; Reus-Smit 1999).

Norms are 'collective expectations about the proper behavior of actors with a given identity' (Katzenstein I 996: 5). Norms form a hierarchy (Busumtwi-Sam \& Bernstein r 997; Reus-Smit I999; Ruggie I 998: 20-I; Wendt \& Duvall i 989:64). This hierarchy is very complex and consists of many different levels, but it may be simplified to only two ideal-typical levels: primary norms and secondary norms (henceforth the latter are referred to merely as norms). Primary norms operate at a deeper level of the social structure. If a norm clashes with a primary norm, it is not reproduced. If an idea conflicts with a primary norm, it is not selected as a norm. If a norm or an idea is compatible with a primary norm, by contrast, it is selected or reproduced as a norm.

Two fundamental insights about identity are critical: first, actors have not only one identity, but multiple identities. Not all identities are relevant for every situation, but certain identities are more salient in certain situations than others. Second, identity is relational. It is shaped by the perception of other actors as the Other. The difference from Other gives meaning to Self (Brubaker i 996; Cottam \& Cottam $200 \mathrm{I}$ ).

Identity shapes norm selection processes in two ways: first, norms and primary norms have to fit in with an actor's definition of Self. Otherwise, they are not selected as norms. The more a norm fits in with Self, the more likely it is to be a primary norm. Second, identity delineates the scope of the applicability of a norm. Depending on the perception of the Other, a norm is selected in an interaction with Other or not. This is a crucial point: norms are not only selected because they 
are compatible with Self; they are also selected because they fit in with the perception of Other. After World War I, for example, the selfdetermination norm changed the political geography of Europe: new states were created, state borders adjusted and autonomy granted to several minorities in East and Central Europe. The norm, however, was not applied to Africa and Asia because, in the perception of the great powers, the European Other differed from the African and the Asian Other.

Thus, whether an actor selects a primary norm or a norm in a given situation or not depends on the configuration of primary norms, norms and identity. Primary norms are selected if they are compatible with the perception of Self and Other. Norms are selected if they are compatible with primary norms as well as the perception of Self and Other. The territorial integrity norm, like any other norm, has to be put into this context of primary norms and norms as well as identity, in order to understand why it is selected by Self in a given encounter with Other.

\section{RESEARGH DESIGN}

This section outlines the map for the empirical research. It chooses a criterion for the identification of regions and sub-regions. Based on this criterion, it identifies the member states of the West Africa and the Horn of Africa sub-regions. It then defines the key variables and concepts of this study, and outlines three steps for the exploration of the relationship between the configuration of primary norms, norms and identity on the one hand, and the management of border disputes on the other.

The criterion employed in this study for the identification of the member states of a sub-region is that states are self-conscious that they constitute a sub-region. A sub-region, therefore, is socially constructed. ${ }^{1}$ Using this criterion, West Africa and the Horn can be identified without too much ambiguity. West Africa consists of those states that are members of the Economic Community of West African States (ECOWAS), by far the most important international organisation both in the economic and in the security realm - in the sub-region. There are sixteen members: Benin, Burkina Faso, Cape Verde, Ivory Coast, The Gambia, Ghana, Guinea, Guinea-Bissau, Liberia, Mali, Mauritania, Niger, Nigeria, Senegal, Sierra Leone and Togo.

Membership in the primary sub-regional international organisation also helps to identify the countries of the Horn of Africa. The InterGovernmental Authority on Development (IGAD) has seven members. 
Two of these members perceive themselves primarily as part of another sub-region: Kenya and Uganda have made, together with Tanzania, impressive steps towards regional integration. ${ }^{2}$ Thus, five countries remain: Djibouti, Eritrea, Ethiopia, Somalia and Sudan.

The dependent variable in this study is the management of border disputes. A border dispute is defined as a conflict between two states arising from the claim of at least one of these states to a part of the territory or, in extreme cases, to the entire territory that is administered by the other state. In order to ensure comparability of the cases, only disputes over land borders between sovereign states are addressed. This filter excludes two classes of border disputes: maritime disputes and disputes involving at least one European colonial power. ${ }^{3}$

Slightly modifying Ogley's definition ( I99 I : 2, 205), I define conflict management as the resolution, mitigation or prevention of escalation of conflict, i.e. the propensity of one party or several parties to 'hurt, damage, destroy or frustrate' another party or other parties. Thus, a border dispute is successfully managed if the dispute is resolved, mitigated or at least prevented from escalation. Conflict management is regarded as failure if it cannot prevent escalation. I use a clear criterion for the failure to prevent escalation: the outbreak of inter-state war, as defined by Small and Singer ( $1982: 3^{6-58}$ ). A conflict is an inter-state war if the actors are sovereign states and the number of casualties exceeds I, ooo per year. ${ }^{4}$

The independent variable is the configuration of primary norms, norms and identity. The presence and absence of a normative consensus as well as the relationship between Self and Other is measured through the analysis of speeches, treaties and communiqués as well as surveys of journals and newspapers. This study focuses on two norms: similarly to Zacher (200I: 2I5), the territorial integrity norm is defined as the proscription against force being used to change the territorial status quo between states. The decolonisation norm is defined as the proscription against any impediments to the right of self-determination for colonised peoples. The relationship between the independent and the dependent variable is explored in three steps: first, the configuration of norms and identity in West Africa and the Horn of Africa are juxtaposed. Second, the impact of the different configurations on the management of border disputes is put under scrutiny. Third, alternative explanations are controlled for. 
GONFIGURATION OF PRIMARY NORMS, NORMS AND IDENTITY

There is a region-wide consensus in Africa on decolonisation as a primary norm. This consensus is a reaction to centuries of oppression and exploitation by foreign powers and precedes the independence of African states. In 1945, the Manchester Congress Declaration of the Colonial Peoples of the World (quoted in Langley r 973: 355) put the primary norm in the following words: "We affirm the right of all colonial peoples to control their own destiny. All colonies must be free from foreign imperialist control, whether political or economic.' At the same Congress, participants agreed that, in principle, they agreed with the Atlantic Charter. It was also agreed, however, that the struggle against colonialism constitutes an exception. The Declaration to the Colonial Powers emphasised that the use of force is permissible as a last resort to achieve the goal of independence (Langley r 973: 354). Thus, decolonisation is a primary norm. It trumps conflicting norms, in this case the principles of the Atlantic Charter.

The framework of the Organisation of African Unity (OAU) reflects the fact that decolonisation has remained a primary norm after most African states had become independent. According to its Charter, one of the purposes of the OAU is to 'eradicate all forms of colonialism from Africa'. Cervenka (ig69: i3) goes so far as to suggest that African leaders interpreted the Charter 'as a common weapon for the liberation of Africa'.

Dedicated to this goal, the first two resolutions of the OAU dealt with decolonisation. More importantly, the OAU created the Liberation Committee, which held its first meeting only a month after the creation of the OAU. The Communique of the first session of the Liberation Committee (quoted in Ansprenger 1975: 40) echoes the declarations of the Manchester Congress. Decolonisation is a primary norm that trumps other norms. Any means may be used in the struggle for decolonisation:

Where ... the colonialist power shows no sign or willingness to recognize the right of the people concerned to self-determination and Independence, the Committee will use All means at its disposal to help the oppressed people to achieve speedy and effective independence.

The primary norm of decolonisation facilitated the selection of the territorial integrity norm among West African states. Initially, the selection of the territorial integrity norm was contested. Two groups advocated different sets of norms for independent Africa. The 
Casablanca Group advocated the creation of a powerful supranational organisation to achieve African unity and to counter the perceived balkanisation of Africa by European powers. The Brazzaville Group, by contrast, advocated state sovereignty, the territorial status quo and territorial integrity.

In I963, the Addis Ababa Conference succeeded in bridging the gap between the two groups. Apart from rationalist causes ${ }^{5}$ for this success, the primary norm of decolonisation facilitated the reaching of a consensus: first, the primary norm demanded a compromise between the two groups. An internally divided Africa would not only be unable to fight colonialism, but would also be prone to neo-colonialisation. As van Walraven (I999: I25) points out, the compromise that African states agreed upon was that 'states were the instrument for the continent's reunification'. Thus, the sovereignty and the territorial integrity of African states were guaranteed, while the dream of African unity remained alive.

Second, changing borders was perceived as an act of colonialism. If African states did not agree on the maintenance of the territorial status quo and territorial integrity, they would open the door to African imperialism. Mali's president, Modibo Keita (quoted in Touval ig67: I04), put this in the following words: 'We must take Africa as it is, and we must renounce any territorial claims, if we do not wish to introduce what we might call black imperialism.'

In West Africa, there has been agreement that colonialism is European colonialism. The liberation struggle was directed against white colonialism. From ig6o onwards, the struggle was directed against Portugal, Rhodesia and South Africa. In the early i $960 s$, for example, Côte d'Ivoire's President Félix Houphouet-Boigny (quoted in Amate I986: 212) equated colonialism in Africa with 'the criminal obstinacy of Portugal ... and ... the apartheid system that is held in honour in South Africa - that apartheid, which is the great shame of our continent'.

The pattern of state-making in West Africa explains why only European states have been perceived as colonial powers. The whole of West Africa was colonised by European states (with the exception of Liberia from the mid-nineteenth century onwards). African states did not participate in the scramble for Africa and in expansion at the cost of other African states. When the decolonisation process finally yielded independence for most West African states, only one state would obstinately deny independence: Portugal, a European power. Of course, the perception of colonialism as European colonialism is not 
confined to West Africa. It is shared by most African states, because state-building processes have been similar across most sub-regions.

In the Horn of Africa, however, state-building processes have been different. The core state of the sub-region, Ethiopia, was - with the brief exception of Italian occupation - not colonised, and exhibited many features of an imperial state. Most importantly, Ethiopia tried to extend the frontiers of the state and include new peripheries into the state by wars of territorial conquest and agreements with European colonial powers. Commenting on Ethiopia's foreign policy, Lewis (I980: 248) speaks of 'Ethiopia's inherent expansionist dynamic', Farer (I 979: I 20) of 'Ethiopia's black imperialism'.

Two Ethiopian expansions would haunt the Horn of Africa for some time to come: the annexations of the Haud and Ogaden regions, and Eritrea. Control over the predominantly Somali-inhabited Haud and Ogaden was transferred to Ethiopia in I 948. Four years later, Eritrea became a federated territory of Ethiopia with considerable autonomy. Both territorial changes were a result of Ethiopia's skilful diplomacy with European powers and the United States. In 1962, Ethiopia reduced Eritrea to a mere province in a centralised state. The abolition of federal institutions and Eritrea's autonomy was a violation of international commitments, but neither the UN nor the OAU reacted to these violations (Young r99 I: 57).

Due to this history of state-making, there is no consensus on who constitutes a colonial power in the Horn of Africa. Ethiopia, Djibouti and the Sudan do not perceive any other state in the Horn as a colonial power. Yet Somalia has perceived Ethiopia as a colonial state. A clear indication of this is the emphasis of Somali leaders on General Assembly Resolutions I5I4 and I54I. Parts of the Preamble of the Treaty of Friendship and Co-operation between Somalia and the Soviet Union, for example, are taken word for word from these resolutions (see Ottaway I982: 3 I I). Resolution I5I4 was adopted in I96o under the title Declaration on the Granting of Independence to Colonial Countries and Peoples. In speaking of colonialism in 'all its forms and manifestations', the resolution adopted a wide definition of colonialism. As Resolution I 54 I clarified, this definition included nonEuropean colonialism (Reisman i983: i6 r). Eritrea has also perceived Ethiopia as an imperial state. The construction of an Eritrean identity is intertwined with the liberation struggle against Ethiopia. Eritrea has portrayed itself as colonised and subjugated by Ethiopia and defined itself to a considerable extent by constructing Ethiopia as the colonial Other (Abbay i 998). 
In sum, decolonisation is a primary norm in Africa. What makes the configuration of primary norms, norms and identity in West Africa so different from the Horn of Africa is that states in the Horn have perceived a state in their sub-regional system as a colonial state, whereas West African states have equated colonialism with European imperialism.

THE MANAGEMENT OF BORDER DISPUTES

The different configuration of norms and identity in West Africa and in the Horn of Africa had a profound impact on the management of border disputes in these two sub-regions. West African states have not perceived any other West African state as a colonial power. They directed the liberation struggle against European colonialism. In relations with one another, they have selected the territorial integrity norm. Border disputes, therefore, have not erupted in war.

As Table I shows, border disputes have been a regular feature of state interactions in West Africa, but none of the disputes erupted into war. ${ }^{6}$ Most disputes were resolved by agreement. ${ }^{7}$ The border disputes between Guinée and Liberia about the Mount Nimba region, as well as between Côte d'Ivoire and Liberia about the area between the Cess and Cavally rivers, stemmed from the French expansion of its colonies Guinée and Côte d'Ivoire at the expense of Liberia's hinterland in the I880s and i 89os. When Guinée and Côte d'Ivoire became independent, the border was disputed by Liberia, but the latter soon accepted the status quo in agreements with Guinée in I96o and Côte d'Ivoire in i 96 I. Four more disputes were resolved by agreement: between Mali and Mauritania about the Hodh desert border and the Savannah region from Djel Mael to Queneibe in I 963 ; between Niger and Upper Volta about the entire border from the Mali to the Dahomey border in I964; between Ghana and Upper Volta about a 50 mile strip at their common border in I964; and, finally, between Ghana and Côte d'Ivoire about the Sanwi-inhabited area of Côte d'Ivoire in I989. ${ }^{8}$

These agreements typically include an implicit reference to the territorial integrity norm. The preamble of the agreement between Mali and Mauritania, for example, invokes the United Nations Charter, which postulates this normative consensus. The accord (quoted in Brownlie I979: 408) is made 'conformément ... aux principes de la charte des Nations Unies'. ${ }^{9}$ Similar formulations are used in the treaty between Niger and Upper Volta and in a Joint Communiqué that comments on the treaty between Ghana and Upper 
TABLE I

Management of border disputes in West Africa

\begin{tabular}{|c|c|c|c|}
\hline Conflicting States & Disputed border & Year $(\mathrm{s})$ & Conflict management \\
\hline Liberia - Guinea & Mount Nimba region & I958-6o & Negotiations lead to agreement \\
\hline Mali-Mauritania & $\begin{array}{l}\text { (a) Hodh desert border; } \\
\text { (b) Savannah region from Djel Mael to } \\
\text { Queneibe }\end{array}$ & I $95^{8-63}$ & Negotiations lead to agreement \\
\hline Ghana-Côte d'Ivoire & $\begin{array}{l}\text { Sanwi-inhabited area of Côte d'Ivoire } \\
\text { (irredentism) }\end{array}$ & I959-89 & Negotiations lead to agreement \\
\hline Liberia-Côte d'Ivoire & Area between Cess and Cavally Rivers & I96o & Negotiations lead to agreement \\
\hline Ghana-Togo & $\begin{array}{l}\text { (a) Ewe-inhabited area of Ghana } \\
\text { (irredentism) } \\
\text { (b) All of Togo }\end{array}$ & I $960-75$ & Negotiations lead to disengagement \\
\hline Dahomey-Nigeria & $\begin{array}{l}\text { Yoruba-inhabited areas of Dahomey } \\
\text { (irredentism) }\end{array}$ & I96o & Negotiations lead to disengagement \\
\hline Dahomey-Niger & Island of Lete in Niger River & I963 & Negotiations lead to disengagement \\
\hline Upper Volta (Burkina Faso)-Niger & $\begin{array}{l}\text { Entire border from Mali to Dahomey } \\
\text { border }\end{array}$ & I $963-87$ & Negotiations lead to agreement \\
\hline Mali-Upper Volta (Burkina Faso) & Agacher Strip & I $960-88$ & $\begin{array}{l}\text { Negotiations lead to agreement on and } \\
\text { acceptance of international arbitration }\end{array}$ \\
\hline Ghana-Upper Volta & 50 mile strip at border & I 964-66 & Negotiations lead to agreement \\
\hline
\end{tabular}

Sources: Brecher and Wilkenfeld (1997), Brownlie (1979), Huth (1998), Touval (1972), Waters (1969: I86-9), as well as Africa Contemporary Record, Annual Register, Keesings's Contemporary Archives, and, finally, 'Africa News', in Lexis/Nexis (Dayton, OH: Reed Elsevier [computer file], 2001). The classification of conflict management is largely taken from Touval (1972). 
Volta. ${ }^{10}$ The treaty between Upper Volta and Mali outlines, as the purpose of the agreement, facilitating a peaceful settlement of the dispute and 'definitely to renounce the use of force' in any dispute between the two countries. ${ }^{11}$

In a number of cases no agreement was reached, but disengagement took place through negotiations: at the beginning of the ig6os, there was a border dispute between Dahomey and Niger about the island of Lete in the Niger River. Although negotiations did not resolve the issue, disengagement occurred. In i 96o, Nigeria claimed the Yorubainhabited areas of Dahomey, but negotiations led to disengagement. The border dispute between Ghana and Togo was particularly grave. Soon after independence, Togo claimed the Ewe-inhabited area of Ghana. The latter responded to the irredentist threat by claiming the whole of Togo. All of these cases may now be considered resolved: Ghana and Togo concluded an agreement to normalise their relations in I 984 ; Benin and Niger, as well as Benin and Nigeria, only experienced problems about border demarcation in the 1980 s and i 99os, but not disputes about border delineation.

The diplomatic discourse in these disengagement cases reflects the consensus on territorial integrity in West Africa. This applies even to the conflict between Ghana and Togo, the most serious conflict among those cases that ended in disengagement. Tensions between the two countries rose high from the beginning of the I 960 s to the mid-i 970 os. $^{12}$ Nevertheless, the emphasis on territorial integrity was the leitmotiv of official statements of both governments. The following Joint Communiqué, worded by the leaders of Ghana and Togo, Kwame Nkrumah and Nicolas Grunitzky in I 963 , is telling with regard to the significance of this norm: The relations between the two states should rest on the 'respect on both sides for the territorial integrity of each state' ${ }^{13}$ Equally telling is the following statement by the government of Togo from the mid-i 97os. After outlining justifications for the Togolese irredentist claim, the statement emphasises: 'However, it is obvious to the outside observer that Togo is not seeking a quarrel with her neighbours; one thing is certain, sooner or later a peaceful solution will be found to this problem. ${ }^{14}$

Finally, one border dispute was resolved by international arbitration. The border dispute between Mali and Burkina Faso stopped short of escalating into full-scale war. The dispute about the Agacher Strip began in I960. Fighting, involving regular troops, took place in I 975 . Approximately fifty-five people died. This has been the most serious border clash between regular troops at the borders of West African 
TABLE 2

Management of border disputes in the Horn of Africa

\begin{tabular}{|c|c|c|c|}
\hline Conflicting States & Disputed border & Year(s) & Conflict management \\
\hline Ethiopia-Somalia & Haud and Ogaden regions & I $955^{-89}$ & $\begin{array}{l}\text { Escalation into war in } \\
\text { I } 977 / 78 \text {, negotiations lead to } \\
\text { disengagement }\end{array}$ \\
\hline Ethiopia-Sudan & Major Gwynne Line & I 965 & Negotiations lead to agreement \\
\hline Djibouti-Eritrea & Sultanate of Raheita & I 996 & $\begin{array}{l}\text { Disengagement without } \\
\text { negotiations }\end{array}$ \\
\hline Eritrea-Ethiopia & Border from Badme to Bure & I $998-00$ & Escalation into war \\
\hline
\end{tabular}

Sources: as for Table I.

countries. Nevertheless, the scale of violence was too limited to allow for a categorisation of the conflict as a war. The two countries agreed on a cease-fire in December i985, on international arbitration by the International Court of Justice in I986, and accepted its verdict in an agreement signed in 1988 .

The territorial integrity norm again shaped diplomatic discourse. When Burkina Faso and Mali agreed for the first time to submit the dispute to arbitration in 1983 , for example, the Preamble of the agreement emphasised the norm. The agreement was made in order to 'achieve as rapidly as possible a settlement of the frontier dispute between them, based in particular on respect for the principle of the infrangibility of frontiers ..., 15

As Table 2 shows, the pattern of conflict management in the Horn of Africa is markedly different from West Africa. Two out of four border disputes erupted into full-scale war. Only two disputes were managed successfully. ${ }^{16}$ The dispute between Ethiopia and Sudan about their common border concentrated on the Major Gwynn Line, the southern part of the border between the two countries. Starting in I 965 , Ethiopia contested the boundary on the grounds that the line was delineated and demarcated unilaterally by Britain, and, therefore, could not bind Addis Ababa. In I 967, however, the two governments accepted the Major Gwynn Line with minor rectifications in a Joint Communiqué. Second, a border dispute between Djibouti and Eritrea arose about the sultanate of Raheita, when Eritrea became independent. The sultanate is now part of Djibouti, but Eritrea claimed part of it as its own territory on grounds of Italian colonial maps. In I996, diplomats reported that troops of Djibouti and Eritrea clashed in 
the sultanate. The dispute, however, did not escalate into war. Disengagement took place without negotiations. ${ }^{17}$

The remaining two border disputes escalated into war. Both wars were directed against a perceived colonial power, Ethiopia, in the relations with which territorial integrity was trumped by the primary norm of decolonisation. Somali nationalists claimed the Somaliinhabited Haud and Ogaden regions from Ethiopia already in colonial times. As soon as Somalia became independent, the government formulated the unification of all Somalis in a Greater Somalia as the central purpose of the new state. Two serious crises with Ethiopia followed: disengagement without negotiations took place in I96r, disengagement through negotiations in 1964. In 1977, however, tensions escalated into full-scale war despite a series of mediation attempts, in particular by the OAU.

During the war, Somalia's foreign minister (quoted in Healy ig8 I : 24) made clear that he regarded Ethiopia as a colonialising state and, therefore, that decolonisation trumped territorial integrity: territorial integrity 'does not apply to Somali territory colonised by Ethiopia. This principle concerns sovereign states and not colonial states. Ethiopia is a colonial state ... The population of the Ogaden has the right to self-determination.' Immediately after the war, the Somali government issued a similar statement (quoted in Healy i 98 I : 24):

The Somali Democratic Republic respects lawful boundaries and the principle of territorial self-determination and all other relevant rules of International Law in the resolution of the current problem. On the other hand, the Ethiopian position is simply Imperial.

The war ended in 1978 with an Ethiopian military victory. A new prolonged crisis occurred from I 987 to I 989 . In this case, negotiations, facilitated by the mediation of OAU and IGADD, and by the need of both governments to concentrate on their country's internal wars, led to disengagement.

After Eritrea became independent, relations between Ethiopia and Eritrea were initially cordial. Ethiopia's ruling Ethiopian Peoples' Revolutionary Democratic Front (EPRDF) had fought together with Eritrea's ruling Eritrean People's Liberation Front (EPLF), now renamed the People's Front for Democracy and Justice, against the Derg regime in Addis Ababa. With the EPRDF in power in Addis Ababa, Eritrea's othering of Ethiopia as a colonial state seemed to be a thing of the past. The border dispute with Ethiopia, however, revived the image of Ethiopia as a colonialist Other. 
After independence, Eritrean President Isaias Afwerki emphasised the need to be alert even during times of peace. In the President's Message to the Eritrean People in r994 (quoted in Tronvoll r999: I 055), for example, Isaias cautioned that 'we have to be as resolute in time of peace as in time of war'. In I997, Ethiopia produced a map of its Tigray province that included areas that Eritrea considered its territory. Suddenly, Ethiopia appeared to Eritreans once more as an imperialist, expansionist state (Gilkes \& Plaut I999: I9).

Eritrea employed maximum force to repel the perceived threat to fall victim to Ethiopia's expansionism once more. After negotiations failed, Eritrea changed the territorial status quo in and around Badme by resorting to full-scale war in May i998. Isaias ( I998: 3) blamed the war on an Ethiopia that he perceived through the lens of the history of Eritrea's liberation struggle. He alleged that 'there is a trend of expansionist policy on the Ethiopian side. The idea of creating a Greater Tigray has always been there.'

Eritrean observers of the border dispute believe that 'things have not changed since the time of Menelik II. Ethiopians have always been obsessed with the sea' (Dahli 2000: I), that the 'old Ethiopian foreign policy tactic is repeating itself' (Tekle 2000: I), even that 'their insane dream is to enslave the Eritrean people as well as plunder the country' (Asghedom I999: I). In short, history has haunted Ethio-Eritrean relations once more. Eritrea interpreted the actions of Ethiopia through the lens of a formerly colonised and subjugated people that had the resolve to fight for its sovereign statehood in its historic boundaries (i.e. its borders as an Italian colony).

From Badme, the war extended as far as Bure in the southeast. The number of fatalities was extraordinarily high because most of the fighting was trench warfare. It is estimated that between 50,000 and I oo, ooo soldiers were killed. ${ }^{18}$ In December 2000, Eritrea and Ethiopia concluded the Algiers Agreement, according to which the delineation of the disputed border would be decided upon by the Eritrea-Ethiopian Boundary Commission, located in The Hague.

In brief, absent a clash between the territorial integrity norm and the primary norm of decolonisation, West African states select the territorial integrity norm to deal with border disputes. These disputes are not necessarily resolved, but they do not escalate into war. Borders are not changed by force. In the Horn of Africa, by contrast, there are state dyads in which the primary norm of decolonisation and the territorial integrity norm clash. Given the primacy of the decolonisation norm, the territorial integrity norm is not selected when a claiming 
state perceives the Other as an imperialist state. Thus, border disputes in the Horn of Africa have been more likely to escalate into war than in West Africa.

\section{GONTROLLING FOR ALTERNATIVE EXPLANATIONS}

Two objections could be made against the argument developed in the previous sections: first, this study compares cases that are not comparable. Due to the nature of the conflicts, border disputes in West Africa were easier to solve than in the Horn. Second, the ideational factors that are critical to my argument are merely epiphenomenal. Material factors constitute the true origins of state interaction. This section addresses these two possible objections. ${ }^{19}$ I contend that, while some of the alternative explanations seem to explain the success and failure of conflict management in particular cases, none of them can account for the patterns of conflict management in West Africa and the Horn.

\section{Types of conflict}

The differences in conflict management could stem from the possibility that the kinds of conflict in the Horn were more difficult to manage than the ones in West Africa. Yet even if a more rigid typology of conflicts is introduced, the argument of this study holds. Land border disputes may be classified into territorial and positional disputes. Territorial disputes are conflicts arising from state A claiming at least a part of the territory that belongs to state $\mathrm{B}$ at the time the claim is made. Territorial disputes can be further divided into irredentist and non-irredentist territorial disputes. Positional disputes, by contrast, are border conflicts in which the boundary is incompletely defined (Matthews i970: 339-42). If a difference is made between territorial and positional disputes, the number of similar cases narrows down to one positional dispute in the Horn, Ethiopia-Eritrea, and three positional disputes in West Africa: Dahomey - Niger, Upper Volta Ghana, Upper Volta - Mali. Despite the similarity of these conflicts, however, war erupted in the Horn, but not in West Africa.

The war between Somalia and Ethiopia was an irredentist territorial dispute, as were three cases in West Africa: Ghana-Côte d'Ivoire, Ghana - Togo, and Dahomey - Nigeria. Doubts could be raised as to whether this class of irredentist territorial disputes consists of sufficiently similar cases. Sanwi irredentism (Ghana-Côte d'Ivoire) was much

weaker than Somali irredentism in the Ogaden. A similar argument 
could be made with regard to Yoruba irredentism (DahomeyNigeria). Yet, there are some striking similarities between Ewe and Somali irredentism, apart from the fact that both are territorial disputes. First, the protest of the Ewe against the partition of their land and for reunification dates back to colonial times, as it does in the case of the Somalis. Second, in both Somalia and Togo, the heads of state were particularly affected by the partition, arguably the latter even more than the former. Somalia is an ethnically homogenous country but clan politics plays an important role. Members of Siyad Barre's extended clan are from the Ogaden in Ethiopia. In Togo, the Ewe are one of four major ethnic groups. Sylvanus Olympio started his political career as a spokesperson for the reunification of his Ewe people in the I940s (Lipschutz \& Rasmussen I986: I 83). At the beginning of the i 960 s he became the first president of independent Togo. Olympio, however, refrained from the use of force, as did his successors in power. Barre, Somalia's leader, did not.

\section{Distribution of power}

Paul (1994:5-7) distinguishes between two power-based explanations of war and peace: power parity and power preponderance. Several authors (Claude i 964; Ferris I973) argue that power parity preserves peace: powerful states are likely to initiate war against weak states. Yet states refrain from initiating war if a balance of power exists in which no single state or alliance of states has overwhelming preponderant power. Power transition theorists (Organski ig68; Weede i976), by contrast, contend that preponderance preserves peace. A preponderant power is immune from attack due to its superior capabilities. Only when a challenger comes close to the preponderant power's capabilities does it initiate war. None of these power-based explanations, however, can explain the patterns of conflict management either in West Africa or in the Horn of Africa.

In West Africa, two cases seem to support the power preponderance hypothesis: Ghana refrained from escalating its conflict with Ivory Coast in the beginning of the I 960 s due to, it could be argued prima facie, Ivory Coast's preponderant power, which was reinforced by its extraordinarily close ties with Paris and the lack of a potent patron on Ghana's side. A similar argument could be made with regard to the dispute between Guinea-Bissau and Senegal. The former did not resort to war, because of the power preponderance of the latter.

There are, however, at least three West African cases that contradict 
the power preponderance hypothesis and for which an argument could be made that power parity preserved peace: Mali and Mauritania, during their border dispute from $195^{8}$ to 1963 , were roughly equal parties. In addition to similar domestic military and economic capabilities, they were both allied with France. The same applies to the disputes between Dahomey and Niger in I963 as well as to the dispute between Mauritania and Senegal in r 989 .

In the Horn of Africa, power preponderance may account for the management of the dispute between Djibouti and Eritrea. Djibouti has remained a quasi-protectorate of France, and Paris had the capability to deter Eritrea. The power preponderance hypothesis also seems to be able to account for the settling of the dispute between Ethiopia and Sudan. The latter refrained from an attack, it could be argued, because of the former's power preponderance.

Yet neither power preponderance nor power parity can account for the wars that took place. All inter-state wars have been asymmetric wars. The weaker state attacked the stronger: Somalia waged war against Ethiopia in $1977 / 78$, and Eritrea initiated war against Ethiopia in I $998 .^{20}$ Neither of the two rival explanations under scrutiny, however, can account for asymmetric wars. The power parity hypothesis predicts that peace is achieved by a balance of power, because unless a preponderant power is balanced, war is likely to occur. In an asymmetric war, however, the weaker power initiates war despite its weakness. The power preponderance hypothesis predicts that an unequal distribution of power prevents war, because the weaker power is deterred from attacking. In an asymmetric war, however, the weaker power attacks despite this unequal distribution of power (Paul i 994).

Neither power parity, nor power preponderance, therefore, can explain the difference in the management of border disputes between West Africa and the Horn of Africa. At first glance, there is some evidence that each of the two power-based hypotheses may explain certain West African cases, and that the power preponderance hypotheses may explain two cases in the Horn. Yet neither of these two hypotheses can account for the patterns of border dispute management in West Africa and the Horn.

\section{Distribution of economic capabilities}

Numerous studies on conflict management in Africa argue that peace among African states is maintained because African states do not have the economic resources to wage war. Aluko (1977:3), for example, 
contends that 'without any strong economic base at home, none of them [African states] could really afford to pursue really vigorous, or adventurous policies abroad'. The problem with this argument is that it cannot account for the variation of the dependent variable under scrutiny. According to this argument, inter-state wars (which are vigorous and adventurous indeed) are unlikely to take place in the whole of Africa. The relations among West African states do not contradict this argument, but the relations among states in the Horn do.

Only a modified argument about the lack of economic capabilities that takes differences between African countries into account could be a plausible rival explanation. There would be prima facie evidence for the contention that economic resources make states less likely to go to war, if those states that refrained from escalating their border disputes had fewer economic resources than those states that did go to war. This, however, is not the case. The Horn of Africa, where two wars were fought, is more poverty-stricken than West Africa. The Horn's repeated tragedies of mass starvation speak volumes about its lack of economic resources. So do macro-economic data: when Ethiopia and Somalia fought in the Ogaden in 1977, their Gross National Product (GNP) per capita ranked I 7 and I I 6 , respectively, out of I 2 I countries that were analysed by the World Bank. No African country ranked lower (World Bank i 979: 6). On the eve of the war between Eritrea and Ethiopia, the two states ranked ig8 and 209 out of 209 analysed countries (World Bank i 999: i 5).

Economic capabilities of West African states, measured by GNP, are significantly higher than those of states in the Horn, but nevertheless their border disputes did not escalate into war. To give only a few examples for the time period between ig6o and i 999: the GNP of Nigeria, the highest in West Africa, was persistently more than triple Ethiopia's, which has the highest GNP in the Horn, and even Ivory Coast's GNP, ranked only second in West Africa, has been persistently higher, throughout the ig8os even double. The GNP per capita of Benin, Ivory Coast, The Gambia, Ghana, Guinea and Senegal in West Africa has been persistently higher than Sudan's and Eritrea's. The lowest GNP per capita of all states in West Africa and in the Horn throughout the ig8os and ig9os was Ethiopia's (World Bank 200 I).

\section{Impact of the global system}

Sub-regional systems are, by their very nature, open systems. The regional system and the global system make an impact on a sub- 
regional system. This study has already dealt with the regional system. It emphasised that the region-wide consensus on decolonisation as a primary norm is a critical part of the explanation of the research puzzle, but that an exclusive focus on the regional level is insufficient.

What about the global system? The impact of the global system has varied in the sub-regions under scrutiny. Two arguments need to be discussed: first, it has been suggested (Kacowicz I 997) that the absence of inter-state war in West Africa is, inter alia, a function of France's role in West Africa. ${ }^{21}$ Second, it has been argued (Lefebvre I 992, I 995) that the conflicts in the Horn of Africa are a function of global conflicts that the former are embedded in.

Kacowicz describes the role of France as stabilising, without, however, clearly specifying how Paris stabilises the relations among West African states. Whatever stabilising role is ascribed to France, it is important to note that no border dispute has escalated into war in the whole of West Africa, regardless of whether both conflicting states had close ties to Paris, whether both states did not, or whether only one of the states did. To give only a few examples: both Dahomey and Niger were allied with France in I 963 . Yet neither Ghana nor Upper Volta had close ties to France during their border dispute from ig64 to i 966 (the latter had temporarily ceased its ties with Paris). Côte d'Ivoire did have strong ties to France during its border dispute with Liberia in I 960 , but Liberia did not. ${ }^{22}$

The impact of extraregional international dynamics on the subregional system of the Horn is disputed. Lefebvre ( I 992, I 995) argues that the causes and dynamics of conflict in the Horn are primarily external. He contends that the East-West rivalry was at the root of the Horn's conflicts during the Cold War. After this antagonism had come to an end, the Horn became the battleground of secularist versus Islamist conflicts. According to these arguments, the pattern of failed conflict management in the Horn is a function of extra-subsystemic factors. Other authors (Buzan i 983: 96; Markakis i 99 I), by contrast, contend that the causes and dynamics of the Horn's conflicts are primarily sub-regional. According to this contention, the pattern of failed conflict management in the Horn is a function of the sub-regional system.

Evidence suggests the validity of the latter argument and contradicts the former. The end of the Cold War has not changed the pattern of conflict management in the Horn. There has been one inter-state war during the Cold War (Ethiopia-Somalia) and one after the Cold War (Eritrea-Ethiopia). Likewise, Lefebvre's argument that wars are now 
fought along the cleavage of religion is problematic with regard to the pattern of conflict management. The inter-state war between Ethiopia and Eritrea broke out although, using Lefebvre's terms, these two 'secular' states were part of a US-engineered alliance against 'Islamist' Sudan. Lefebvre's argument cannot account for the outbreak of this war.

This study has argued that different configurations of primary norms, secondary norms and identity account for the different patterns of border dispute management in West Africa and in the Horn of Africa. West African states have selected the territorial integrity norm, because the norm was compatible with the primary norm of decolonisation. In the Horn of Africa, by contrast, the primary norm has clashed with the secondary norm of territorial integrity. Border disputes, therefore, have been more likely to escalate into war.

These results have three implications for further research. First, it is insufficient to analyse the impact of norms on state behaviour by isolating them from the social context in which they are embedded. This study has simplified this context by using an analytical triangle consisting of primary norms, secondary norms and identity. More research is necessary to improve our understanding of the social context. This applies in particular to the configuration of norms. How can we best make sense of the hierarchy of norms? A simplification of this hierarchy into two levels is only a starting point.

Second, International Relations scholars tend to over-generalise. Mostly drawing from European and North American experiences, dynamics of state interaction are assumed to be constant across regions, often even across time. For many research endeavours, this assumption is unwarranted. The turn towards regional analysis helps to uncover the problems of the assumption. Given the size of the African continent, some research questions even require scrutiny on the sub-regional level. Needless to say, even this level is often too wide a brush, and more detailed analysis is necessary.

Third, ideational factors such as norms and identity profoundly influence success and failure of conflict management. In order to improve our understanding of peaceful change, therefore, more research needs to be directed towards why ideas, in particular fundamental ideas, such as primary norms and the perception of Self and Other, change. One cause of deep ideational change may be what Adler ( I99 I : 55) called a 'cognitive punch'. Catastrophic events such 
BORDER DISPUTES IN AFRICAN REGIONAL SUB-SYSTEMS 389 as wars and dramatic economic depression may facilitate fundamental ideational change.

\section{NOTES}

I. At the core of several definitions of regions is this constructivist element. See, for example, Morgan (1997: 30). For an overview of attempts to define regions, see Lake (1997: 46-8).

2. The now revived integration even includes such symbolically important aspects as an East African passport and an East African flag.

3. The rationale for this is as follows: maritime disputes lack the ideational aspect of border disputes. Disputes over land usually have an ideational component. Land is considered as ancestral homeland. This makes the management of territorial disputes more difficult. The Israeli-Palestinian conflict is an example of this dynamic. Maritime borders lack this kind of emotional attachment. Disputes involving a colonial power are excluded because, given the rapid erosion of legitimacy for European empires from the i 960 s onwards, African states were very likely to claim colonial territory but, due to the enormous power disparities, very unlikely to escalate a conflict. Again, this dynamic is different from inter-African relations. If this filter would not be used, the remarkable difference between the management pattern in West Africa and the Horn would even magnify. Maritime border disputes abound in West Africa, but not in the Horn. The number of border disputes involving a colonial power is approximately the same in the two subregions. None of the excluded border disputes escalated into war.

4. This definition is widely used in social science, although it is not undisputed. The criterion of I,Ooo casualties is somewhat arbitrary. Yet for the purposes of this study, the definition is well suited, because there are no ambiguous cases. Either the number of casualties clearly exceeded I,ooo or it was clearly lower. (Even if the number were reduced to Ioo, it would not affect the coding of the cases.)

5. Without doubt, Foltz (I973), Herbst (I 989) and Zacher (200 I) correctly point out that the calculations of leaders influence the agreement on territorial integrity. Yet there are, in addition to this, also sociological factors that profoundly influence the selection of the territorial integrity norm.

6. I do not code the border incident between Mauritania and Senegal as a border dispute. The conflict was caused by clashes between Mauritanian herders and Senegalese farmers. None of the governments of either country challenged the territorial status quo. Even if classified as a border dispute, the number of casualties was too low to allow for a coding of this incident as a war.

7. I code a border dispute as resolved by agreement if there is consensus among the parties about the delimitation of the border. Delimitation is the principal agreement on a border as described in a written accord, a map or a chart. Demarcation, by contrast, is the process of physically marking the border on the ground. For more detailed definitions see Brownlie (r 979: 4).

8. In several cases, these agreements were only the beginning of an exact definition of the boundary, including demarcation. Such agreements followed in the disputes between Mali and Mauritania in I987, and between Burkina Faso and Niger in 1987. In the case of Ghana-Côte d'Ivoire, considerable disengagement had already begun in the mid-rg6os, although the agreement was concluded no sooner than the late ig8os, and even then some technical details remained to be resolved.

9. 'In accordance ... with the principles of the Charter of the United Nations ... .' Traité de délimitation de frontières entre la République Islamique de Mauritanie et la République du Mali (quoted in Brownlie I 979: 408).

Io. The treaty between Niger and Upper Volta is published in Fournal Officiel de la République du Niger, Niamey, 24.3. I966; parts of the Joint Communiqué in Africa Research Bulletin 34, I967: 8 I 7 .

I I. Keesing's Contemporary Archives 2 I, I I-I 7.8.1975: 27268.

12. Togo, also a former German colony, was divided between Britain and France, as was Cameroon. British Togoland voted in a plebiscite for the unification with Ghana, whereas French Togoland became independent. In the plebiscite, however, the Ewe people in British Togoland (and a number of smaller ethnic groups: Adeles, Akpossos and Komdombas), in contrast to other ethnic groups in the north of the territory, had voted in favour of unification with French Togoland, because the border cuts through Ewe-inhabited areas. Ghana responded to the 
irredentist threat by claiming the whole of Togo, justifying this claim by Nkrumah's panAfricanist ideology.

I3. Africa Diary 3, 8, I6-22.2.1963: 1008.

14. Official statement, published in The Times, London, 28. I. 1977, quoted in Brownlie (1979:

277). Brownlie explains the background of this statement: on 2 I January, the Togo-Press published an article by K. B. Johnson, the Togolese minister of information, in which the latter gave justifications for Togo's irredentism. Since the article caused some irritation, the Togolese government published an official statement in The Times that makes clear that its irredentist goals were only to be achieved by peaceful means.

I 5. Special Agreement between the Government of the Republic of the Upper Volta and the Government of the Republic of Mali for the Submission to a Chamber of the International Court of Justice of the Frontier Dispute between the two Governments, I983. This treaty is published in the United Nations Treaty Series.

I6. In accordance to the filters outlined in the section on research design, I exclude the border disputes between the French Territory of the Afars and Issas with Ethiopia and Somalia from this analysis, because the former was a French protectorate. Moreover, I do not code the case of Djibouti and Somalia as a border dispute. Somalia renounced its claims to Djibouti before the latter gained its independence from France. In 1976, Somalia declared at the United Nations General Assembly that it would recognise the territorial integrity of an independent Djibouti. This commitment was reiterated in a Joint Communiqué by the foreign ministers of Somalia and France in 1976 (East 1982: I I I-13). Additionally, Siad Barre, Somalia's leader, is quoted as having commented on Djibouti's independence: 'Somalia owes it to itself' to protect the new state's independence. The quote is taken from Africa Contemporary Record io, I977/78: B2o6.

I 7. I do not code the 1998/99-conflict between Djibouti and Eritrea as a border dispute. Eritrea accused Djibouti of supporting Ethiopia in the Ethiopian-Eritrean War. Djibouti perceived this as a threat, and put its armed forces on alert. But these tensions were caused by the ramifications of the Ethiopian-Eritrean war, not by a border dispute.

18. Mail and Guardian, Johannesburg, 25.5.2000.

19. I do not deal with the impact of ECOWAS at length. ECOWAS's conflict management apparatus has made a major contribution to the management of internal wars, but has not changed the pattern of management of border disputes. With or without ECOWAS, no border dispute has escalated into war in West Africa. The same applies to economic interdependence: Increasing levels of economic interdependence, facilitated by ECOWAS, probably further contribute to successful conflict management, because it becomes more and more costly to wage war. Yet even at a time when economic interdependence was low, in particular in the early ig6os between former French and former British colonies, border disputes were successfully managed.

20. Ethiopia is the potential hegemon in the sub-region. It has also been militarily the most powerful one, especially after it changed alliances from the United States to the Soviet Union and Cuba in May 1977. Despite this, Somalia attacked two months later. Eritrea not only risked a war against a stronger power, but also its alignment with the United States and the West. Washington perceived Sudan as a threat to its interests in the Horn and, therefore, balanced with Eritrea and Ethiopia against Khartoum.

2 I. The French role has undoubtedly been stabilising for leaders. As Clapham (1996: 77-105) shows, France has provided security for the leaders of its ex-colonies and for internal statehood. The question here, however, is whether the successful management of border disputes in West Africa has been a function of French policies.

22. For a more detailed overview of the difference in the strength of ties between France and African states, see Luckham (1982) and Grey (1990).

\section{REFERENGES}

Abbay, A. 1998. Identity Filted or Re-imagining Identity? Lawrenceville, NJ: Red Sea Press.

Adler, E. I 99 I. 'Cognitive evolution: a dynamic approach for the study of international relations and their progress', in E. Adler \& B. Crawford, eds., Progress in Postwar International Relations. New York: Columbia University Press, $43^{-88}$.

Afwerki, I. I998. 'President Isaias Afwerki answered questions from foreign journalists', Eritrea Profile, Asmara, 30 June. 
Aluko, O. I977. 'The determinants of the foreign policies of African states', in O. Aluko, ed., The Foreign Policies of African States. Toronto: Hodder \& Stoughton, I-23.

Amate, C. I986. Inside the $O A U$ : Pan-Africanism in practice. London: Macmillan.

Ansprenger, F. I 975. Die Befreiungspolitik der Organisation für Afrikanische Einheit $(O A U): 1963$ bis I975. Munich: Kaiser.

Asghedom, T. I 999. 'Behind the Ethiopian authorities' wars of aggression against Eritrea', Eritrea Profile, Asmara, 27 Feb.

Bernstein, S. 2002. The Compromise of Liberal Environmentalism. New York: Columbia University Press.

Brecher, M. \& J. Wilkenfeld. I997. A Study of Crisis. Ann Arbor, MI: University of Michigan Press.

Brownlie, I. I979. African Boundaries: a legal and diplomatic encyclopaedia. Berkeley, CA: University of California Press.

Brubaker, R. I996. Nationalism Reframed: nationhood and the national question in the New Europe. Cambridge University Press.

Busumtwi-Sam, J. \& S. Bernstein. I 997. 'Institutionalization in world politics'. Unpublished paper. Simon Fraser University and University of Toronto.

Buzan, B. I983. People, States and Fear: the national security problem in international relations. Brighton: Wheatsheaf Books.

Cervenka, Z. ig69. The Organization of African Unity and its Charter. New York: Praeger.

Clapham, C. I996. Africa and the International System: the politics of state survival. Cambridge University Press.

Claude, I. I964. Power and International Relations. New York: Random House.

Cottam, M. \& R. Cottam. 200 I. Nationalism and Politics: the political behavior of nation states. Boulder, CO: Lynne Rienner.

Dahli, H. 2000. 'Ethiopia's obsession with the Red Sea', Eritrea Profile, Asmara, 20 July.

East, R. I982. 'Djibouti - Somalia', in A. Day, ed., Borders and Territorial Disputes. Harlow: Longman, I I I-I 3 .

Farer, T. I979. War Clouds on the Horn of Africa: the widening storm. New York: Carnegie Endowment for International Peace.

Ferris, W. 1973. The Power Capabilities of Nation States. Lexington, MA: Lexington Books.

Finnemore, M. \& K. Sikkink. I999. 'International norm dynamics and political change', in P. Katzenstein et al., eds., Exploration and Contestation in the Study of World Politics. Cambridge, MA: MIT Press, 247-77.

Florini, A. I996. 'The evolution of international norms', International Studies Quarterly 40, 3: $363^{-89}$.

Foltz, W. I973. 'Political boundaries and political competition in Tropical Africa', in S. Eisenstadt and S. Rokkan, eds., Building States and Nations: analyses by region. Beverly Hills, CA: Sage, $357-83$.

Foltz, W. I99I. 'The Organization of African Unity and the resolution of Africa's conflicts', in F. Deng \& I. Zartman, eds., Conflict Resolution in Africa. Washington: Brookings, 347-66.

Gilkes, P. \& M. Plaut. I999. War in the Horn: the conflict between Eritrea and Ethiopia. London: Royal Institute of International Affairs.

Grey, R. I990. 'A balance sheet on external assistance: France in Africa', Fournal of Modern African Studies 28, I : IOI-I 4 .

Healy, S. i98 I. 'The principle of self-determination: still alive and well', Millennium i o, I : I4-28.

Herbst, J. I989. 'The creation and maintenance of national boundaries in Africa', International Organization 43, 4: 673-92.

Huth, P. I998. Standing Your Ground: territorial disputes and international conflict. Ann Arbor, MI: University of Michigan Press.

Jackson, R. \& C. Rosberg. I982. 'Why Africa's weak states persist: the empirical and the juridical in statehood', World Politics 35, I : I-24.

Jackson, R. \& C. Rosberg. I986. 'Sovereignty and underdevelopment: juridical statehood in the African crisis', Journal of Modern African Studies 24, I : I-3 I.

Jackson, R. \& C. Rosberg. i 987 . 'Quasi-states, dual regimes, and neoclassical theory: international jurisprudence and the Third World', International Organization 4I, 4: 5I9-49.

Kacowicz, A. I997. "Negative" international peace and domestic conflicts: West Africa, i 957-1996', Fournal of Modern African Studies 35, 3: 367-85.

Katzenstein, P. I996. 'Introduction: alternative perspectives on national security', in P. 
Katzenstein, ed., The Culture of National Security: norms and identity in world politics. New York: Columbia University Press, I-32.

Lake, D. i 997. 'Regional security complexes: a systems approach', in D. Lake \& P. Morgan, eds., Regional Orders: building security in a new world. University Park, PA: Pennsylvania State University Press, $45^{-67}$.

Langley, J. 1973. Pan-Africanism and Nationalism in West Africa: 19oo-1945. Oxford: Clarendon Press.

Legro, J. I997. 'Which norms matter? Revisiting the 'failure' of internationalism', International Organization $5 \mathrm{I}, \mathrm{I}: 3^{\mathrm{I}-6}-{ }_{3}$.

Lefebvre, J. 1992. 'The geopolitics of the Horn of Africa', Middle East Policy I, i : 7-22.

Lefebvre, J. I 995. 'Post-Cold War clouds on the Horn of Africa: the Eritrea-Sudan crisis', Middle East Policy 4, I : 34-49.

Lewis, I. I980. A Modern History of Somalia: nation and state in the Horn of Africa. New York: Longman.

Lipschutz, M. \& R. Rasmussen. 1986. Dictionary of African Historical Biography. Berkeley, CA: University of California Press.

Luckham, R. 1982. 'French militarism in Africa', Review of African Political Economy 24: 55-84.

Markakis, J. I991. 'The bone of contention in the Horn of Africa', in G. Nzongola-Ntalaja, ed., Conflict in the Horn of Africa. Atlanta, GA: African Studies Association Press, I9-25.

Matthews, R. 1970. 'Interstate conflict in Africa: a review', International Organization 24, 2 : $335^{-60}$.

Morgan, P. I997. 'Regional security complexes and regional orders', in D. Lake \& P. Morgan, eds., Regional Orders: building security in a new world. University Park, PA: Pennsylvania State University Press, 20-42.

Ogley, R. i99i. Conflict under the Microscope. Aldershot: Avebury.

Organski, A. ig68. World Politics. New York: Alfred A. Knopf.

Ottaway, M. I982. Soviet and American Influence in the Horn of Africa. New York: Praeger.

Paul, T. I 994. Asymmetric Conflicts: war initiation by weaker powers. Cambridge University Press.

Reisman, W. 1983 . 'Somali self-determination in the Horn', in I. Lewis, ed., Nationalism \& Self Determination in the Horn of Africa. London: Ithaca Press, ${ }_{5} \mathrm{I}^{\mathrm{I}}-73$.

Reus-Smit, C. I999. The Moral Purpose of the State: culture, social identity, and institutional rationality in international relations. Princeton, NJ: Princeton University Press.

Ruggie, J. 1998. Constructing the World Polity: essays on international institutionalization. New York: Routledge.

Small, M. \& J. Singer. 1982. Resort to Arms: international and civil wars, 1816-1980. Beverley Hills, CA: Sage.

Tekle, A. 200o. 'Old Ethiopian foreign policy tactic is repeating itself', Eritrea Profile, Asmara, 29.9.2000.

Touval, S. 1967. 'The Organization of African Unity and African borders', International Organization 2 I, I : $102-27$.

Touval, S. 1972. The Boundary Politics of Independent Africa. Cambridge, MA: Harvard University Press.

Tronvoll, K. I999. 'Borders of violence-boundaries of identity: demarcating the Eritrean nation-state', Ethnic and Racial Studies 22, 6: 1037-6o.

van Walraven, K. I 999. Dreams of Power: the role of the Organization of African Unity in the politics of Africa: 1963-1993. Aldershot: Ashgate.

Waters, R. I 969. 'Appendix I : Inter-African boundary disputes', in C. Widstrand, ed., African Boundary Problems. Uppsala: Almquist \& Wiksells.

Weede, E. I 976 . 'Overwhelming preponderance as a pacifying condition among contiguous Asian dyads, I950-69', Fournal of Conflict Resolution 20, 3: 395-4I I.

Wendt, A. \& R. Duvall. I989. 'Institutions and international order', in E. Czempiel \& J. Rosenau, eds., Global Changes and Theoretical Challenges. Lexington, MA: Lexington Books, $5^{\mathrm{I}-73}$.

World Bank. 1979. World Bank Atlas. Washington, DG: World Bank.

World Bank. I 999. World Bank Atlas. Washington, DG: World Bank.

World Bank. 200 I. World Development Indicators. Washington, DC: World Bank.

Young, C. I99 I. 'Self-determination revisited: has decolonization closed the question?' in G. Nzongola-Ntalaja, ed., Conflict in the Horn of Africa. Atlanta, GA: African Studies Association Press, $4 \mathrm{I}-65$. 
BORDER DISPUTES IN AFRICAN REGIONAL SUB-SYSTEMS 393

Zacher, M. 200 I. 'The territorial integrity norm: international boundaries and the use of force', International Organization 55, 2: 21 5-50.

Newspapers, Newsletters, and Newes Archives

Africa Contemporary Record, London

Africa Diary, New Delhi

'Africa News' in Lexis/Nexis, Dayton, OH

African Research Bulletin, Exeter

The Annual Register: A Record of World Events, Harlow: Longman

Fournal Officiel de la République du Niger, Niamey

Keesing's Contemporary Archives, New York

Mail and Guardian, Johannesburg

The Times, London

Websites

United Nations, United Nations Treaty Series at <http://untreaty.un.org > 